\title{
Risk Factors and Outcome of Medically Treated Acute Coronary Syndromes
}

\author{
Aisha A. Al GHAmDI, FACP, Arab \& Saudi Boards \\ Department of Internal Medicine, Faculty of Medicine, \\ King Abdulaziz University, Jeddah, Saudi Arabia
}

\begin{abstract}
A retrospective study included patients admitted to an intensive care unit with a diagnosis of acute coronary syndrome from January 2000 to December 2003. Three hundred patients' medical histories were reviewed. The underlying risk factors such as a positive family history, diabetes mellitus, hypertension and hyperlipidemia were obtained. The cause for admission, hospitalization duration, complications and mortality were all taken into consideration and compared statistically. Mean age was $55.2 \pm 11.9$ years with the male to female ratio of 5.8:1. Diagnoses at the time of admission were ST elevation myocardial infarction, unstable angina, and non-ST elevation myocardial infarction in $61 \%, 30 \%, 9 \%$ of the patients, respectively. Thrombolytic treatment had been the golden therapeutic option for ST elevation myocardial infarction available in King Abdulaziz University Hospital, used by $78 \%$ of the patients, followed by intravenous anticoagulants and other anti-ischemic medications. The procedures performed were percutaneous coronary angioplasty (3\%), coronary bypass grafting ( $2 \%)$, and cardiac catheterization and angiography for further intervention $(45 \%)$ for the 300 patients, respectively. $26 \%$ of patients developed complications. Mortality was higher among females compared to males $(13.6 \%$ versus $5.9 \%)$. In conclusion male gender, diabetes mellitus, hypertension, hyperlipidemia, positive family history and smoking were the main associated risk factors in our study. ST elevation myocardial infarction was the predominant presentation in our patients. Thrombolytic treatment was the available therapeutic option in our hospital.
\end{abstract}

Keywords: Acute coronary syndrome, Risk factors, Thrombolytic treatment.

Correspondence \& reprint requests to: Dr. Aisha A. Al Ghamdi

P.O. Box 30598, Jeddah 21487 Saudi Arabia

Accepted for publication: 23 February 2005. Received: 24 October 2004. 


\section{Introduction}

Acute coronary syndrome (ACS) is a wide spectrum of definitions covering three important cardiological emergencies; myocardial infarction (MI) whether ST elevation (Q-wave) MI (STEMI) or non-ST elevation (non-Q wave) MI (NSTEMI) and unstable angina (UA) ${ }^{[1]}$. The diagnosis of acute MI relies on the revised criteria established by the World Health Organization (WHO) in $1979^{[2]}$. Two of these criteria were required for diagnosis of an acute STEMI; history of ischemic chest pain, typical electrocardiogram (ECG) pattern including the development of $\mathrm{Q}$ waves and typical elevations in serum markers of myocardial injury, usually creatine kinase (CK MB).

Joint European Society of Cardiology (ESC) and American College of Cardiology Committee (ACC) proposed the following definition of an acute episode, evolving $\mathrm{MI}$ in $2000^{[3]}$. Typical rise and gradual fall (troponin) or more rapid rise and fall (CK MB) of biochemical markers of myocardial necrosis with at least one of the following: Ischemic symptoms, development of pathologic Q waves on the ECG, ECG changes indicative of ischemia (ST segment elevation or depression) and coronary artery intervention (e.g., angioplasty). According to this definition and guidelines published by the ACC and the American Heart Association (AHA) in 2002, UA and NSTEMI differ primarily in whether the ischemia is severe enough to cause sufficient myocardial damage to release detectable quantities of a marker of myocardial injury ${ }^{[3,4]}$.

UA and NSTEMI are frequently indistinguishable at initial evaluation. UA is considered to be present in patients with ischemic symptoms suggestive of an ACS and no elevation in troponins or CK MB, with or without ECG changes indicative of ischemia. Prevalence of ACS may be underestimated because of high percentage of silent ischemia which is thought to account for 75 percent of all ischemic episodes ${ }^{[5]}$. Males have higher incidence of ACS than premenopausal females, but after menopause the incidence in women reaches that in men.

The presence of ischemic heart disease in first degree relatives (before the age of 45-years in males and before 50-years in female) represents a fixed risk factor. Other strongly associated risk factors are hypertension, diabetes mellitus (DM), dyslipedemia, cigarette smoking, obesity, physical inactivity and adverse dietary pattern ${ }^{[6]}$. The ECG is a mainstay in the diagnosis of acute MI, it can also localize it ${ }^{[2,3]}$. Biomarkers of cardiac injury are troponin I and troponin $\mathrm{T}$, creatine kinase $(\mathrm{CK})$ and its isoform CK MB. An elevation in the serum concentration of one or more of the above markers is seen in virtually all patients with an acute $\mathrm{MI}^{[7,8]}$. Serum troponins are the marker of choice because of the high specificity to myocardial injury ${ }^{[9]}$, followed by CK MB. Total CK, lactate dehydrogenase and myoglobin no longer have a major role ${ }^{[7]}$, because they lack the specificity to the heart muscle. 
Once the diagnosis of an acute STEMI is made management of the patient involves the early and simultaneous achievement of several goals, as outlined by a task force of the ACC \& $\mathrm{AHA}^{[10]}$. Relief of ischemic pain, assessment of the hemodynamic state and correction of abnormalities that are present, initiation of reperfusion therapy with primary percutaneous coronary intervention (PCI) or thrombolysis and antithrombotic therapy to prevent rethrombosis of an ulcerated plaque or subtotal stenosis by angiotensin converting enzyme (ACE) inhibitor, beta blockers, statin and anticoagulation, if needed.

\section{Method}

\section{Study Design, Population and Setting}

A retrospective study of the intensive care unit (ICU) at King Abdulaziz University Hospital (KAUH), Jeddah, Saudi Arabia included all patients with a diagnosis of acute coronary syndrome admitted to the ICU from January 2000 to December 2003. A total of three hundred and forty (340) patients were admitted during that period. Forty (40) patients were excluded from the study because of insufficient data and missing medical records.

\section{Data Collection and Statistical Analysis}

Three hundred (300) patients were included in the study. Their demographic features were recorded. It was difficult to calculate the body mass index (BMI) because height could not be assessed nor it was recorded due to critical patients' conditions in the ICU. Cardiac investigations were registered including cardiac enzymes; tryponin I, CK and CK-MB, ECG findings (interpretated by a cardiologist), echocardiography and chest radiography. Diagnosis at admission; STEMI (history of ischemic symptoms suggestive of an ACS with serum elevation in troponins or CK MB and ST elevation in ECG), NSTEMI (history of ischemic symptoms suggestive of an ACS, with serum elevation in troponins or CK MB with out ST elevation in ECG ), UA (history of ischemic symptoms suggestive of an ACS, with no serum elevation in troponins or CK MB, with or without ECG changes indicative of ischemia). Presence of risk factors was reviewed; positive family history of early deaths, $(<45$-years in males, $<50$-years in females), presence of DM which was diagnosed according to American Diabetic Association's criteria ${ }^{[11]}$. Hypertension (patient is known hypertensive or receiving antihypertensive agents or $\mathrm{BP}>140 / 90 \mathrm{mmHg}$ on more than one occasion), presence of Hyperlipidemia (known to have hyperlipidemia or on lipid lowering agent), smoking history (active or passive or 5-year ex-smoker). Other recognizable risk factors like obesity, physical inactivity were not registered because of insufficient data inside the patients' files. Their treatment (thrombolytic, anticoagulant medications and if they needed emergency or elec- 
tive cardiac intervention). Period of ICU staying, pattern of complications and mortality all were recorded. Follow-up treatment by anti-ischemic medications (aspirin, nitrites, ACE inhibitors, beta blockers, calcium channel blockers) and lipid-lowering therapy with a statin was registered. Mortality, risk factors were studied and compared statistically in relation to the age and gender of the patients.

Data analysis was done using statistical package for social sciences (SPSS software ${ }^{[12]}$. Mean \pm SD was calculated for quantitative data and proportions for categorical variables. One-way ANOVA and "student's" $t$-test were used for comparing means of continuous variables. Proportions were compared by Chi-square test and Mantel-Haenszel test if needed. Significance level was set at $<0.05$ throughout the analysis.

\section{Results}

A total of 300 patients were studied. Their mean age was $55.2 \pm 11.9$ years (Range was 20-87 years) with male to female ratio of 5.8:1. STEMI was found in $182(61 \%)$ patients, NSTEMI was found in $27(9 \%)$ patients and UA in 91 $(30 \%)$ patients. Table 1 shows demographic features of each group. High serum tryponin and CK MB were found in all cases of MI (70\%) of all cases. ST elevation was recorded as antroseptal MI in $42 \%$, inferior MI in $42 \%$ and antrolateral in $16 \%$. Chest radiography was abnormal in about one-third (32\%) of all cases. The abnormalities included cardiomegaly, pulmonary congestion and eodema.

TABLE 1. General characteristics of the patients.

\begin{tabular}{|l|c|c|c|c|c|}
\hline \multicolumn{1}{|c|}{ Variable } & $\begin{array}{c}\text { Study Group } \\
\text { N (\%) }\end{array}$ & $\begin{array}{c}\text { STEMI } \\
\text { N (\%) }\end{array}$ & $\begin{array}{c}\text { NSTEMI } \\
\text { N (\%) }\end{array}$ & $\begin{array}{c}\text { UA } \\
\text { N (\%) }\end{array}$ & P Value \\
\hline Total Patients & $300(100.0)$ & $182(61.0)$ & $27(9.0)$ & $91(30.0)$ & \\
\hline Age: $($ mean \pm SD) & $55.2 \pm 11.9$ & $54.8 \pm 12.3$ & $55.3 \pm 10.0$ & $56.0 \pm 11.6$ & 0.8 \\
\hline Sex & $256(85.3)$ & $163(89.6)$ & $22(81.5)$ & $71(78.0)$ & 0.03 \\
\hline Male & $44(14.7)$ & $19(10.4)$ & $5(18.5)$ & $20(22.0)$ & \\
\hline Female & $91(30.3)$ & $54(29.7)$ & $10(37.0)$ & $27(29.7)$ & 0.7 \\
\hline Nationality & $209(69.7)$ & $128(70.3)$ & $17(63.0)$ & $64(70.3)$ & \\
\hline Saudi & \multicolumn{5}{|l}{} \\
\hline Non-Saudi
\end{tabular}

STEMI = ST elevation myocardial infarction.

NSTEMI = non-ST elevation myocardial infarction

$\mathrm{UA}=$ unstable angina

$\mathrm{P}<0.05$ is significant 
Associated risk factors are illustrated in Table 2 in relation to gender and age. Thrombolytic treatment was given to $142(78 \%)$ of STEMI patients (those who presented within 6 hours of the onset of symptoms). Heparin, aspirin, nitrites were given to all 300 patients regardless of time of presentation. Other antiischemic medications were given which included ACE inhibitors to $245(82 \%)$ patients, beta blockers to $243(81 \%)$ patients and calcium channel blockers to $30(10 \%)$ patients. Lipid lowering agents were used in $161(54 \%)$ patients. Complications developed in $54(30 \%)$ patients in STEMI, $8(30 \%)$ patients in NSTEMI and in 17 (19\%) patients in UA. Table 3 showed different types of complications and their respective ratios. Post MI unstable angina developed in $8 \%$ patients with STEMI, and in 4\% patient with NSTEMI (P 0.02). Cardiogenic shock developed in $12 \%$ with STEMI, in $4 \%$ with NSTEMI and in $6 \%$ with UA (P 0.1). For those who developed post MI unstable angina, percutaneous coronary angioplasty (PTCA) was performed for $9(60 \%)$ patients of them and coronary bypass grafting $(\mathrm{CABG})$ for $6(40 \%)$ patients. Cardiac catheterization and angiography were required for 135 (45\%) patients for possible further interventions. The duration in ICU was $3.3 \pm 3.8$ days (range 1-49 days). Mortality among males was $5.9 \%$ while amongst females was $13.6 \%$. As shown in Table 4 the proportion of mortality among males and females aged less than 50 years was $(5.7 \%, 0 \%)$, respectively, but it differs in those who are older $(6 \%$, $16.7 \%$ ), respectively (P 0.7 ).

TABLE 2. Risk factors of acute coronary syndrome.

\begin{tabular}{|c|c|c|c|c|}
\hline \multicolumn{2}{|c|}{ Risk Factors } & \multirow{2}{*}{$\begin{array}{c}\text { Total Number } \\
\text { N (\%) }\end{array}$} & \multirow{2}{*}{$\begin{array}{c}\begin{array}{c}\text { Age Groups } \\
\text { N (\%) }\end{array} \\
88(30.0) \\
168(70.0)\end{array}$} & P Value \\
\hline \multirow{2}{*}{ Gender } & $\begin{array}{l}\text { Male } \\
\qquad 550 y \\
\geq 50 y\end{array}$ & & & \multirow{2}{*}{0.03} \\
\hline & $\begin{array}{l}\text { Female } \\
\qquad 50 y \\
\geq 50 y\end{array}$ & $44(14.7)$ & $\begin{array}{r}8(20.0) \\
36(80.0) \\
\end{array}$ & \\
\hline \multirow{2}{*}{ Family History } & $\begin{array}{l}\text { Male } \\
\qquad 50 y \\
\quad \geq 50 y\end{array}$ & $42(16.4)$ & $\begin{array}{l}24(57.1) \\
18(41.9)\end{array}$ & \multirow{2}{*}{0.07} \\
\hline & $\begin{array}{l}\text { Female } \\
\qquad 50 \mathrm{y} \\
\quad \geq 50 \mathrm{y}\end{array}$ & $5(11.4)$ & $\begin{array}{l}2(40.0) \\
3(60.0)\end{array}$ & \\
\hline \multirow{2}{*}{ Diabetes Mellitus } & $\begin{array}{l}\text { Male } \\
\qquad 50 \mathrm{y} \\
\quad \geq 50 \mathrm{y}\end{array}$ & $149(58.2)$ & $\begin{array}{r}32(21.5) \\
117(78.5)\end{array}$ & \multirow{2}{*}{0.05} \\
\hline & $\begin{array}{l}\text { Female } \\
\quad<50 y \\
\geq 50 y\end{array}$ & $26(59.1)$ & $\begin{array}{r}4(15.4) \\
22(84.6)\end{array}$ & \\
\hline
\end{tabular}


Table 2. Contd.

\begin{tabular}{|c|c|c|c|c|}
\hline \multicolumn{2}{|c|}{ Risk Factors } & $\begin{array}{c}\text { Total Number } \\
\text { N (\%) }\end{array}$ & $\begin{array}{c}\text { Age Groups } \\
\text { N (\%) }\end{array}$ & P Value \\
\hline \multirow{2}{*}{ Hypertension } & $\begin{array}{l}\text { Male } \\
\qquad 50 y \\
\geq 50 y\end{array}$ & $110(43.0)$ & $\begin{array}{l}36(32.7) \\
74(67.3)\end{array}$ & \multirow{2}{*}{0.06} \\
\hline & $\begin{array}{l}\text { Female } \\
\quad<50 \mathrm{y} \\
\geq 50 \mathrm{y}\end{array}$ & $25(56.8)$ & $\begin{array}{r}3(12.0) \\
22(88.0) \\
\end{array}$ & \\
\hline \multirow{2}{*}{ Hyperlipidemia } & $\begin{array}{l}\text { Male } \\
\qquad 50 \mathrm{y} \\
\quad \geq 50 \mathrm{y}\end{array}$ & $141(55.1)$ & $\begin{array}{l}59(41.8) \\
82(58.2)\end{array}$ & \multirow{2}{*}{0.07} \\
\hline & $\begin{array}{l}\text { Female } \\
\quad<50 \mathrm{y} \\
\geq 50 \mathrm{y}\end{array}$ & $20(45.5)$ & $\begin{array}{r}4(20.0) \\
16(80.0)\end{array}$ & \\
\hline \multirow{2}{*}{ Smoking } & $\begin{array}{l}\text { Male } \\
\quad<50 y \\
\geq 50 y\end{array}$ & $156(60.9)$ & $\begin{array}{l}68(43.6) \\
88(56.4)\end{array}$ & \multirow{2}{*}{0.5} \\
\hline & $\begin{array}{l}\text { Female } \\
\qquad 50 y \\
\quad \geq 50 y\end{array}$ & 7 (15.9) & $\begin{array}{l}2(28.6) \\
5(71.4)\end{array}$ & \\
\hline
\end{tabular}

$\mathrm{N}=$ number of patients; $\%=$ percentage; $\mathrm{y}=$ years, $\mathrm{P}<0.05$ is significant.

TABLE 3. Complications and outcome of acute coronary syndrome.

\begin{tabular}{|l|c|c|c|c|}
\hline \multicolumn{1}{|c|}{ Variable } & $\begin{array}{c}\text { STEMI } \\
\mathbf{N}(\mathbf{\%}) \\
\mathbf{1 8 2}(\mathbf{1 0 0})\end{array}$ & $\begin{array}{c}\text { NSTEMI } \\
\mathbf{N}(\mathbf{\%}) \\
\mathbf{2 7}(\mathbf{1 0 0})\end{array}$ & $\begin{array}{c}\text { UA } \\
\mathbf{N ~ ( \% )} \\
\mathbf{9 1}(\mathbf{1 0 0})\end{array}$ & P Value \\
\hline Complications & $54(29.7)$ & $8(29.6)$ & $17(18.7)$ & 0.1 \\
\hline CHF & $5(2.7)$ & $2(7.4)$ & $6(6.6)$ & 0.2 \\
\hline RHF & $1(0.5)$ & $0(0.0)$ & $1(1.1)$ & 0.6 \\
\hline LHF & $23(12.6)$ & $2(7.4)$ & $5(5.5)$ & 0.2 \\
\hline Arrhythmia & $19(10.4)$ & $3(11.1)$ & $6(6.6)$ & 0.3 \\
\hline Cardiogenic Shock & $22(12.1)$ & $1(3.7)$ & $5(5.5)$ & 0.1 \\
\hline Post MI UA & $14(7.7)$ & $1(3.7)$ & $0(0.0)$ & 0.02 \\
\hline ICU Duration (mean \pm SD) & $3.5 \pm 4.3 \mathrm{~d}$ & $4.1 \pm 3.7 \mathrm{~d}$ & $2.8 \pm 2.7 \mathrm{~d}$ & 0.07 \\
\hline Mortality & $15(8.2)$ & $2(7.4)$ & $4(4.4)$ & 0.5 \\
\hline
\end{tabular}

STEMI = ST elevation myocardial infarction.

NSTEMI = non-ST elevation myocardial infarction

$\mathrm{UA}=$ unstable angina

$\mathrm{P}<0.05$ is significant

$\mathrm{CHF}=$ congestive heart failure

$\mathrm{RHF}=$ right-sided heart failure

$\mathrm{LHF}=$ left-sided heart failure

$\mathrm{d}=$ day $/ \mathrm{s}$ 
TABLE 4. Effect of age and gender on mortality of acute coronary syndrome.

\begin{tabular}{|c|c|c|}
\hline Gender & $\begin{array}{c}\text { Morality } \\
\text { N (\%) }\end{array}$ & P Value \\
\hline $\begin{array}{c}\text { Male } \\
<50 \mathrm{y}=88(30 \%) \\
\geq 50 \mathrm{y}=168(70 \%)\end{array}$ & $5(5.7)$ & 1.0 \\
\multicolumn{2}{|c|}{$\begin{array}{c}10(6.0) \\
15(5.9)\end{array}$} & \\
\hline $\begin{array}{c}\text { Female } \\
<50 \mathrm{y}=8(20 \%)\end{array}$ & $0(0.0)$ & \\
$\geq 50 \mathrm{y}=36(80 \%)$ & $6(16.7)$ & \\
Total $* *$ & $6(13.6)$ & \\
\hline
\end{tabular}

$*$ Total $=\mathrm{N}=256 ;(\%)=100$

$* *$ Total $=\mathrm{N}=44 ;(\%)=100$

\section{Discussion}

Angina is often characterized more as a discomfort than pain, and may be difficult to describe. Terms frequently used by patients included: discomfort, squeezing, tightness, pressure, constriction, burning, heartburn, fullness in the chest, band-like sensation, lump in the throat, ache and toothache (when there is radiation to the lower jaw). It is generally not described as sharp, dull-aching, knife-like, stabbing, or pins and needles-like ${ }^{[13,14]}$. Some patients with an ACS present with atypical symptoms rather than chest pain. In a review of over 430,000 patients with confirmed acute MI from the National Registry of Myocardial Infarction 2, one-third had no chest pain on presentation to the hospital. These patients may present with dyspnea alone, nausea and/or vomiting, palpitations, syncope, or cardiac arrest. They are more likely to be older, diabetic, and women ${ }^{[15]}$. Patients with silent MI are usually under treated and they have an increased in-hospital mortality ${ }^{[15]}$. A potential diagnostic problem is that myocarditis can mimic an acute MI in all major diagnostic features, including chest pain, ECG changes, and a rise in the concentration of serum markers. Myocarditis should be considered in young patients with a clinical presentation of an ACS, particularly those who have a normal coronary angiogram ${ }^{[16,17]}$. The ECG is a mainstay in the diagnosis of acute MI. Patients with a strong clinical history and ST segment elevation or new left bundle branch block should undergo immediate reperfusion therapy with thrombolysis or primary percutaneous coronary intervention.

In our study the majority were having STEMI was $61 \%$ of the study's patients. Two multi-center, international surveys published in 2002 determined the relative frequency of ACS in approximately 22,000 patients; STEMI in $33 \%$, NSTEMI in $25 \%$, and UA in $42 \%[18,19]$. Different percentages were found in our study, which may reflect the different pattern of ACS in our part of 
the world compared to western patients. Also, it may be due to the fact that some patients with NSTEMI and UA were not admitted to the ICU. Only $78 \%$ of patients with STEMI received thrombolytic treatment (those who presented within 6 hours of the onset of symptoms).

Although ACC/AHA guidelines recommended primary PCI, with or without a stent, as an alternative to thrombolytic therapy, we do not have the facilities to do it and most patients had to be transferred to referral hospitals in the area. Best results for PCI we achieved if it is performed as early as possible (3 hours) of symptoms' appearance. Early thrombolytic therapy (6 hours) can be used as alternative to PCI for STEMI, but there is an argument against its use for NSTEMI and $\mathrm{UA}^{[20]}$, and we did not use it for patients STEMI who presented after 6 hours of onset of symptoms and for NSTEMI and UA patients. Intravenous heparin was given to all patients. Antiplatelet agents (aspirin , †dipyridamole, $\uparrow$ ticlopidine, $\uparrow$ clopidogrel and glycoprotein $\mathrm{IIb} / \mathrm{III}$ a receptor in hibitors) have a role in the management of $\mathrm{ACS}^{[21]}$. Aspirin is commonly used (dose of 75 to $150 \mathrm{mg}$ /day) may provide optimal efficacy while limiting toxicity $^{[21]}$, it should be continued indefinitely for ACS patients unless they can not tolerate aspirin because of gastrointestinal intolerance or hypersensitivity. Alternatives in such patients are clopidogrel $(75 \mathrm{mg} /$ day $)$ and, less preferably, ticlopidine $(250 \mathrm{mg} \text { BID })^{[21-23]}$. Our patients were all discharged on aspirin and nitrites.

The most common complication in STEMI patients was heart failure 29 (16\%) patients, followed by cardiogenic shock $22(12 \%)$ patients. $14(7.7 \%)$ patients developed post MI UA in STEMI with (P 0.02). They have very bad course and planned PTCA or CABG were required. Duration of hospitalization and long term mortality rates following MI have fallen substantially with improvements in medical care, including more rapid administration of thrombolytic agents, increased use of primary angioplasty, and more frequent administration of aspirin, beta blockers, and ACE inhibitors, and more frequent risk factor reduction. The improvement in outcome after acute infarction has come from increased use of aspirin and thrombolytic therapy or primary $\mathrm{PCI}^{[24]}$. Another factor may be the greater sensitivity of current techniques for detecting small MIs, which tend to be associated with low mortality rates ${ }^{[25]}$.

Finally, risk factors modification in ACS is the first step to be considered by recognition of ischemic symptoms and early hospital contact. Elevated cardiac enzymes (tryponin, CK MB) and ECG changes are the corner stones of STEMI diagnosis. Primary PTCA is the best approach if it is done as early as possible 3 hours from symptoms' appearance. Early thrombolytic therapy should be considered in hospitals that do not have the facilities for PTCA. If complications developed further cardiac catheterization and angiography should be con- 
sidered. Follow-up by anti-ischemic medications is recommended for a better outcome. Mortality in our study was compared to that which was obtained by Furman et al. ${ }^{[26]}$ from community-based multihospital study, less figures were found by our study ( $8 \%$ versus $14 \%$ ) in STEMI patients and ( $7 \%$ versus $12 \%$ ) in NSTEMI patients. Improvement in survival has been also observed by other studies $^{[27-29]}$.

In our study, higher mortality rate was observed among females compared to males $(13.6 \%, 5.9 \%)$, respectively. Females whose age 50-years and older showed higher mortality $(16.7 \%)$ than younger age group $(0 \%)$ of same gender, and it was about three times that in males at the same age group (6\%), this finding does not agree with Vaccarino et al. ${ }^{[29]}$; who found that mortality rate of women less than 50-years of age was more than twice that for men and concluded that younger women with MI represent a high-risk group. Despite small numbers of females in our study group (15\%) older women represent a highrisk group in contrast to males who represented the majority of our study group $(85 \%)$ only $(30 \%)$ of males represented a high-risk group; those who aged less than 50-years showed higher mortality rate compared to females of the same age group $(5.7 \%, 0 \%)$ respectively, which does not go with (Stone et al. $)^{[30]}$ who found that males older than 75-years of age have three-fold increase in the incidence of death post MI. The gender, age based differences in risk factors, presentations, outcome and mortality were the main concern among our study group. We need larger number of patients to see the cause of these differences, which could not be entirely accounted for by differences in risk factors only and may reflect pathophysiological and anatomical differences between men and women.

\section{References}

[1] Grech ED, Ramsdale DR. Acute coronary syndrome: unstable angina and non-ST segment elevation myocardial infarction. BMJ 2003; 326(7401): 1259-1261.

[2] [No authors listed]. Nomenclature and criteria for diagnosis of ischemic heart disease. Report of the Joint International Society and Federation of Cardiology/World Health Organization task force on standardization of clinical nomenclature. Circulation 1979; 59(3): 607609.

[3] Alpert JS, Thygesen K, Antman E, Bassand JP. Myocardial infarction redefined - a consensus document of The Joint European Society of Cardiology/American College of Cardiology Committee for the redefinition of myocardial infarction. J Am Coll Cardiol 2000; 36(3): 959-969. Erratum in: J Am Coll Cardiol 2001; 37(3): 973.

[4] Braunwald E, Antman EM, Beasley JW, Califf RM, Cheitlin MD, Hochman JS, Jones RH, Kereiakes D, Kupersmith J, Levin TN, Pepine CJ, Schaeffer JW, Smith EE 3rd, Steward DE, Theroux P, Gibbons RJ, Alpert JS, Faxon DP, Fuster V, Gregoratos G, Hiratzka LF, Jacobs AK, Smith SC Jr; American College of Cardiology; American Heart Association. Committee on the Management of Patients With Unstable Angina. ACC/AHA 2002 guideline update for the management of patients with unstable angina and 
non-ST-segment elevation myocardial infarction - summary article: A report of the American College of Cardiology/American Heart Association task force on practice guidelines (Committee on the Management of Patients With Unstable Angina). J Am Coll Cardiol 2002; 40(7): 1366-1374.

[5] Deedwania PC, Carbajal EV. Silent myocardial ischemia. A clinical perspective. Arch Intern Med 1991; 151(12): 2373-2382.

[6] Lowe LP, Greenland P, Ruth KJ, Dyer AR, Stamler R, Stamler J. Impact of major cardiovascular disease risk factors, particularly in combination, on 22-year mortality in women and men. Arch Intern Med 1998; 158(18): 2007-2014.

[7] Zimmerman J, Fromm R, Meyer D, Boudreaux A, Wun CC, Smalling R, Davis B, Habib G, Roberts R. Diagnostic marker cooperative study for the diagnosis of myocardial infarction. Circulation 1999; 99(13): 1671-1677.

[8] Hamm CW, Goldmann BU, Heeschen C, Kreymann G, Berger J, Meinertz T. Emergency room triage of patients with acute chest pain by means of rapid testing for cardiac troponin T or troponin I. N Engl J Med 1997; 337(23): 1648-1653.

[9] Jaffe AS, Ravkilde J, Roberts R, Naslund U, Apple FS, Galvani M, Katus H. It's time for a change to a troponin standard. Circulation 2000; 102(11): 1216-1220.

[10] Ryan TJ, Antman EM, Brooks NH, Califf RM, Hillis LD, Hiratzka LF, Rapaport E, Riegel B, Russell RO, Smith EE 3rd, Weaver WD, Gibbons RJ, Alpert JS, Eagle KA, Gardner TJ, Garson A Jr, Gregoratos G, Smith SC Jr. 1999 update: ACC/AHA Guidelines for the Management of Patients With Acute Myocardial Infarction: Executive Summary and Recommendations: A report of the American College of Cardiology/American Heart Association Task Force on Practice Guidelines (Committee on Management of Acute Myocardial Infarction). Circulation 1999; 100(9): 1016-1030.

[11] Expert Committee on the Diagnosis and Classification of Diabetes Mellitus. Report of the expert committee on the diagnosis and classification of diabetes mellitus. Diabetes Care 2003; 26 (Suppl 1): S5-20.

[12] Nie NH, Hull CH, Jenkins JG, Steinbrenner K, Bent DH. SPSS: Statistical Package for Social Sciences. 2nd ed. New York: McGraw-Hill, 1975: 222-224.

[13] Sampson JJ, Cheitlin MD. Pathophysiology and differential diagnosis of cardiac pain. Prog Cardiovasc Dis 1971; 13(6): 507-531.

[14] Constant J. The clinical diagnosis of nonanginal chest pain: the differentiation of angina from nonanginal chest pain by history. Clin Cardiol 1983; 6(1): 11-16.

[15] Canto JG, Shlipak MG, Rogers WJ, Malmgren JA, Frederick PD, Lambrew CT, Ornato JP, Barron HV, Kiefe CI. Prevalence, clinical characteristics, and mortality among patients with myocardial infarction presenting without chest pain. JAMA 2000; 283(24): 3223-3229.

[16] Sarda L, Colin P, Boccara F, Daou D, Lebtahi R, Faraggi M, Nguyen C, Cohen A, Slama MS, Steg PG, Le Guludec D. Myocarditis in patients with clinical presentation of myocardial infarction and normal coronary angiograms. J Am Coll Cardiol 2001; 37(3): 786-792.

[17] Karjalainen J, Heikkila J. Incidence of three presentations of acute myocarditis in young men in military service. A 20-year experience. Eur Heart J 1999; 20(15): 1120-1125.

[18] Hasdai D, Behar S, Wallentin L, Danchin N, Gitt AK, Boersma E, Fioretti PM, Simoons ML, Battler A. A prospective survey of the characteristics, treatments and outcomes of patients with acute coronary syndromes in Europe and the Mediterranean basin; the Euro Heart Survey of Acute Coronary Syndromes (Euro Heart Survey ACS). Eur Heart $J$ 2002; 23(15): 1190-1201. 
[19] Fox KA, Goodman SG, Klein W, Brieger D, Steg PG, Dabbous O, Avezum A. Management of acute coronary syndromes. Variations in practice and outcome; findings from the Global Registry of Acute Coronary Events (GRACE). Eur Heart $J$ 2002; 23(15): 1177-1189.

[20] Anderson HV. Intravenous thrombolysis in refractory unstable angina pectoris. Lancet 1995; 346(8983): 1113-1114.

[21] Antithrombotic Trialists' Collaboration. Collaborative meta-analysis of randomised trials of antiplatelet therapy for prevention of death, myocardial infarction, and stroke in high risk patients. BMJ 2002; 324(7329): 71-86. Erratum in: $B M J 2002$; 324(7330): 141.

[22] [No authors listed] Collaborative overview of randomised trials of antiplatelet therapy - I: Prevention of death, myocardial infarction, and stroke by prolonged antiplatelet therapy in various categories of patients. Antiplatelet Trialists' Collaboration. $B M J$ 1994; 308(6921): 81-106. Erratum in: $B M J$ 1994; 308(6943): 1540.

[23] Goldstein RE, Andrews M, Hall WJ, Moss AJ. Marked reduction in long-term cardiac deaths with aspirin after a coronary event. Multicenter Myocardial Ischemia Research Group. J Am Coll Cardiol 1996; 28(2): 326-330.

[24] Heidenreich PA, McClellan M. Trends in treatment and outcomes for acute myocardial infarction: 1975-1995. Am J Med 2001; 110(3): 165-174.

[25] Alpert JS. The scarred heart: mortality rates for myocardial infarction in the absence of modern therapy. Arch Intern Med 2002; 162(21): 2411-2412.

[26] Furman MI, Dauerman HL, Goldberg RJ, Yarzebski J, Lessard D, Gore JM. Twentytwo year (1975 to 1997) trends in the incidence, in-hospital and long-term case fatality rates from initial Q-wave and non-Q-wave myocardial infarction: a multi-hospital, communitywide perspective. J Am Coll Cardiol 2001; 37(6): 1571-1580.

[27] Rogers WJ, Canto JG, Lambrew CT, Tiefenbrunn AJ, Kinkaid B, Shoultz DA, Frederick PD, Every N. Temporal trends in the treatment of over 1.5 million patients with myocardial infarction in the US from 1990 through 1999: the National Registry of Myocardial Infarction 1, 2 and 3. J Am Coll Cardiol 2000; 36(7): 2056-2063.

[28] Rosamond WD, Chambless LE, Folsom AR, Cooper LS, Conwill DE, Clegg L, Wang CH, Heiss G. Trends in the incidence of myocardial infarction and in mortality due to coronary heart disease, 1987 to 1994. N Engl J Med 1998; 339(13): 861-867.

[29] Vaccarino V, Parsons L, Every NR, Barron HV, Krumholz HM. Sex-based differences in early mortality after myocardial infarction. National Registry of Myocardial Infarction 2 Participants. N Engl J Med 1999; 341(4): 217-225.

[30] Hochman JS, Tamis JE, Thompson TD, Weaver WD, White HD, Van de Werf F, Aylward P, Topol EJ, Califf RM. Sex, clinical presentation, and outcome in patients with acute coronary syndromes. Global Use of Strategies to Open Occluded Coronary Arteries in Acute Coronary Syndromes IIb Investigators. N Engl J Med 1999; 341(4): 226-232. 


\title{
عو امل الخطورة ونتائج علاج المتلازمة التاجيّة الحادة
}

\author{
عائشة عبده الغامدي

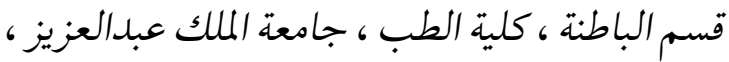

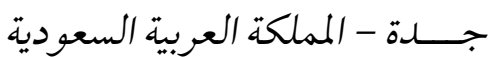

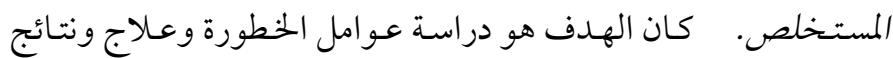

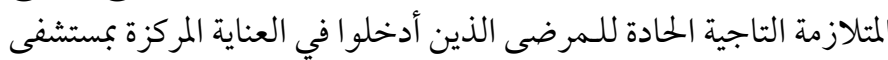

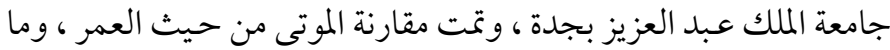

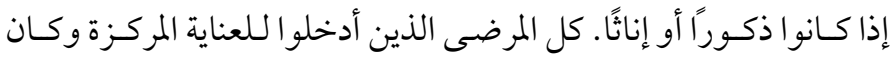

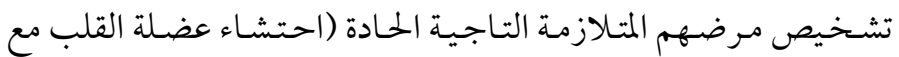

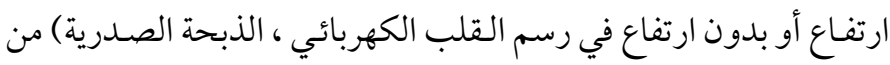

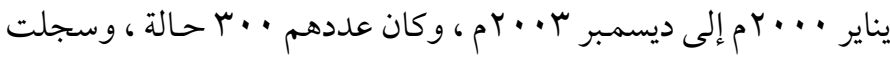

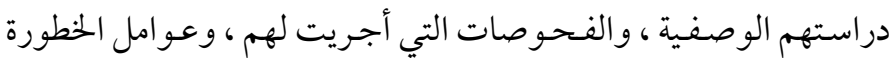

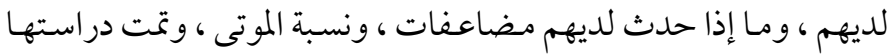

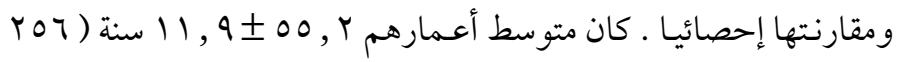

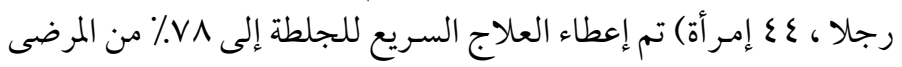

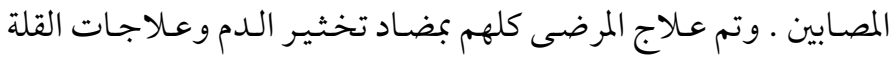

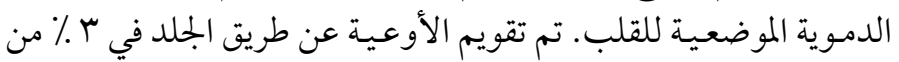

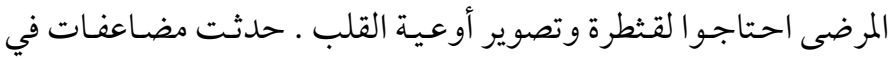

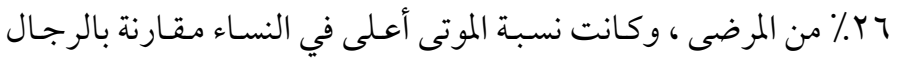

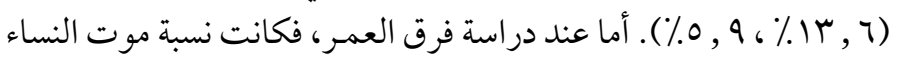

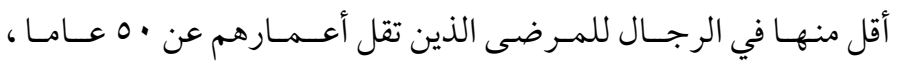

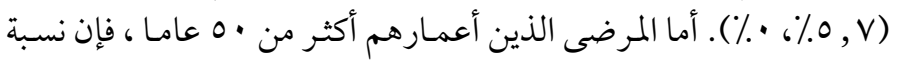

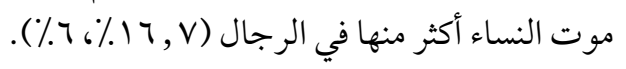

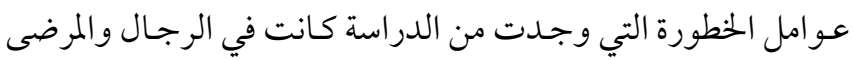

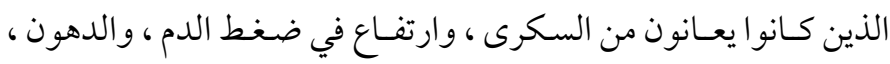

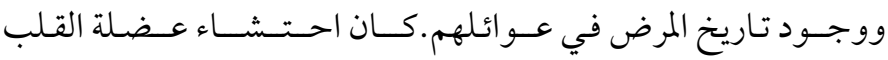
الأكثرتشخيصا ، ونسبة الموت في في النساء أكثر. 